\title{
The Effect of Information Technology Governance and Enterprise Risk Management on the Performance of State-Owned Enterprises in Non-Public Financial Fields Moderated by Corporate Governance
}

\author{
Mochamad Muslih ${ }^{1}$, lis Sugianti ${ }^{2}$, Daulat Freddy Simanjuntak ${ }^{3}$, Dedi Rianto Rahadi ${ }^{4}$ \\ ${ }_{1,2,3}$ STIE Tri Bhakti, Indonesia \\ ${ }^{4}$ President University, Indonesia \\ Email:mochamadmuslih@stietribhakti.ac.id
}

\begin{abstract}
The use of information technology is a necessity and a challenge in this 4th-millennium era. Companies that do not want to use technology that suits their needs will be left behind. The Indonesian government has also required the use of appropriate information technology. The purpose of this study is to evaluate the implementation of the Ministry of SOE Regulation No. Per 02 / MBU / 2013 concerning guidelines for the preparation of information technology management of State-Owned Enterprises (SOE) in the field of nonpublic finance and the implementation of risk management to SOEs that are moderated by corporate governance. The population in this study is State-Owned Enterprises (SOE) in the financial sector. The research sample of 17 SOEs was sampled with the purposive sampling method. The analysis technique used is multiple linear regression. The results showed that IT Governance does not affect firm performance. ERM significantly influences firm performance. Corporate governance that is proxied by the number of audit committee meetings does not moderate IT governance's influence on firm performance and does not mild ERM's effect on firm performance.
\end{abstract}

Keywords: IT Governance, Enterprise Risk Management, Corporate Governance, Firm Performance.

\section{A. INTRODUCTION}

State-Owned Enterprises (SOE) hereinafter referred to as BUMN is one of the actors of economic activities in the national economy based on economic democracy (RI Law No. 19, on BUMN, 2003). Because the management is based on economic democracy, it is necessary to follow market mechanisms and be profit-oriented (Wandeca \& Liza, 2012; Girma et al., 2009). The emergence of BUMN Law No. 19 of 2003, because the role of BUMN in realizing people's welfare is not optimal, its management and supervision need to be carried out professionally, and BUMN management needs to adapt to the increasingly rapid development of the economy and the business world, both nationally and internationally (Alon et al., 2014; Liang et al. 2015).

State-Owned Enterprises (SOE) are important assets owned by the Indonesian state because this business's income will go into the state treasury and be used for various state expenditures. Therefore, state-owned enterprises must have integrity and good performance so that they can always benefit the state. However, in 2019, 
one of the state-owned companies in the financial sector, PT Jiwasraya Insurance, suffered losses related to liquidity pressure problems. This is caused by investing in most of the high-risk assets to pursue high returns. Most of these investment funds are invested in underperforming stocks and mutual funds managed by underperforming investment managers.

In contrast to the performance achieved by PT Savings and Civil Servant Insurance or Taspen (Persero), which recorded a net profit of 388.24 billion rupiahs in 2019. This figure increased by 116.69 billion rupiahs if compared to 2018 profit of 271.55 billion rupiahs or an increase of $42.97 \%$. This surge in performance results from the implementation of TASPEN's strategies and policies in making prudent and safe investments by carefully considering the level of risk accepted, market conditions, liquidity, optimal returns, and conservative reserves to ensure the welfare of participants.

Many factors trigger this phenomenon, including human resources, corporate governance, budgets, company assets, corporate culture, authority, risk management, and good information technology governance. However, according to researchers, the most decisive triggering factors in the financial sector are information technology governance, risk management, and corporate governance. In particular, for all State-Owned Enterprises, the government has established policies related to the implementation of Information Technology Governance and good corporate governance and the application of risk management.

Ministry of State-Owned Enterprises Regulation number Per 02 / MBU / 2013 concerning guidelines for the preparation of information technology management for State-owned enterprises stipulates the regulations for implementing information technology in State-Owned Enterprises. The government's consideration in regulating the application of information technology is that information technology has enormous benefits in business development, so it needs to be developed in a directed and measured manner in State-Owned Enterprises to support business strategies. In 2018, the government issued a Regulation of the Minister of StateOwned Enterprises per-02/MBU/02/2018 concerning the Principles of Information Technology Governance in the Ministry of State-Owned Enterprises. Besides, the Regulation of the Minister of State-Owned Enterprises No: Per-01 /MBU/2011 concerning the Implementation of Good Corporate Governance in State-owned enterprises Article 25, where the Board of Directors is required to build and implement an integrated corporate risk management program which is part of the implementation of the GCG program. The audit committee is an important corporate governance mechanism. Since its inception, the audit committee has changed significantly and is now considered one of the characteristics of effective corporate governance. The number of meetings held by the audit committee is expected to boost firm performance with the meetings' reports. This research tries to study the number of audit committee meetings that moderate IT Governance and Enterprise Risk Management on the performance of State-Owned Enterprises, whether every meeting held by the audit committee can strengthen the influence of information 
technology governance and risk management on firm performance. The frequency of meetings held by the audit committee is expected to produce reports or recommendations that can evaluate information technology governance and risk management. The number of audit committee meetings conducted makes something that can improve firm performance.

Research conducted by Carl \& Les (2011), the main trend that emerges from the investigation is that adherence to governance principles is a myth and does not guide decision making for IT projects. Lunardi et al. (2013), in their research, found that companies that adopt information technology governance practices have increased performance, especially concerning profitability. The effect of adopting information technology governance mechanisms on financial performance is more visible in the year after adoption, not in the year of adoption. Andrianti and Setiawan (2018), in their research, said that the implementation of IT Governance needs to be done to deal with problems such as damage that can result in loss of data so that it can interfere with the company's operational activities, considering that the recovery efforts carried out require a lot of time and resources. Uki (2019), in his research, shows a positive relationship between IT Resources and the successful implementation of IT Governance.

Kanhai \& Ganesh (2014), concluded based on the results of their research on bank ERM practices in Zimbabwe that the success of ERM implementation is determined by the adequacy of its risk management structure, the quality of its organizational culture, the intensity of the regulatory environment, and the size of the bank. Sanjaya and Nanik (2015), show that together ERM has a significant effect on firm value, but partially ERM does not substantially affect firm value. Mulyasari, et al (2016), based on their research results, the implementation of Enterprise Risk Management in public companies at the Indonesia Stock Exchange does not provide significant results on company value. Muslih (2018), conducted a study to study the benefits of ERM in improving firm performance, and the research results showed a significant relationship between ERM and firm performance.

Research conducted by Ramlan, Rifa and Fauziati (2013), Octavianto, Widagdo, and Chariri (2014), Mulyadi (2017), and Muslih (2019b) state that the number of audit committee meetings has no significant effect on company performance. Mulyati \& Muslih (2020), said that audit committee meetings did not increase the audit committee's quality and amount of analysis, so the impact on performance was not there. Onasi \& Robin (2016), state that the number of audit committee meetings positively affects firm value.

From the discussion above and research conducted previously, the research questions consist of whether IT governance affects company performance? Whether enterprise risk management affect firm performance? Whether corporate governance moderates the influence of IT governance on firm performance? Whether corporate governance moderates the effect of enterprise risk management on firm performance? 


\section{B. LITERATURE REVIEW}

The Grand Theory of this research is agency theory. Agency theory is based on the concept of separation between owner and company management. Neither owner nor management seeks to maximize its interests. Therefore, Jensen and Meckling (1976), stated that management, as the fund owner (principal), does not always maximize the fund owner's interests. This is what causes the agency problem. This agency problem will generate costs, which are referred to as agency costs. The implementation of information technology governance and risk management within the company will reduce agency problems because, in its application, it will produce something that can improve the company's performance, which also maximizes value to shareholders. The openness of accounting information can be used to reduce adverse selection problems. A high level of financial information disclosure can provide investors with knowledge equivalent to that of managers. Managers' opportunistic nature resulting from moral hazard problems can be reduced by maximizing management remuneration schemes based on company performance. In short, investors can expect corporate governance to help solve agency problems and ensure adequate returns from their investment in the company (Dedi et al., 2015).

The contract between owner and agent is the motivation for each party to perform its performance. Today's companies have separated managerial ownership and control, and not all high-level management members are company owners (Yi Lin, 2010). In this separation, agency problems are inevitable. As a result, it is the company manager's duty and all stakeholders' interests to minimize conflicts of interest (Yi Lin, 2010). To reduce agency conflicts or problems, a supervisory mechanism is needed for company management-one of the instruments used in GCG. GCG is a system that provides guidelines and principles for aligning different interests, especially the parts of managers and those of shareholders (El-Chaarani, 2014). By minimizing the conflict of interest that occurs, it is hoped that the agent can act following the owner's interests, namely increasing company returns so that company performance increases.

\section{Firm Performance}

Firm performance is the company's ability with existing resources to provide value to the company. By measuring the company's performance, we can measure its efficiency and productivity and measure its performance. Company performance is an overall display of the company's state during a certain period, which results from its operational activities in utilizing its resources (Helfert, 1996 in Cecilia Srimindarti; Fokus Ekonomi, 2004 in Widodo, 2011).

Company performance can be measured using financial ratios (Prasinta, 2012). Investors make investments, one of which is by looking at the profitability ratio (Prasinta, 2012). The profitability ratio used in this study uses Return on Assets (ROA) because it can provide an overview of the return on returns that investors can get on their investment (Prasinta, 2012). Besides, with ROA, investors can see how 
companies optimize their assets to maximize profits, which is also the goal of GCG to use assets efficiently and optimally (OECD, 2004).

\section{Information Technology Governance}

Research shows that IT's application has shifted from a technology issue to a management and management issue. IT must be managed like any other company asset. The application of IT in a company can be made well if supported by IT governance from planning to implementation (Weil \& Ross, 2004; Bowen et al., 2007).

IT governance is a structure of relationships and processes to regulate and control the company to achieve defined corporate goals with added value while balancing risks with the value obtained from implementing IT and its procedures (The IT, 2000a). Information technology governance is not a separate field from corporate management but is a component of corporate administration as a whole (The IT, 200b).

The concept of IT Governance is a way of managing the use of information technology in an organization. IT Governance combines good practices from planning and organizing, developing and implementing, delivery and support, and monitoring information systems' performance to ensure that information and related technology supports the achievement of organizational goals and missions. According to IT Governance (ITGI, 2012), IT Governance is the executive responsibility of a board of directors and top-level management. Governance consists of leadership, organizational structure, and processes that ensure that the organization and IT strategy and goals are maintained and sustainable. The Ministerial Regulation of SOE Per-02/MBU/02/2018 states that Information technology in the Ministry of State-Owned Enterprises needs to be managed and utilized effectively and efficiently, management and utilization of Information Technology can run well, be coordinated, and achieve Good Information Technology Governance (GITG), it is necessary to have provisions governing information technology governance.

\section{Enterprise Risk management}

Mamduh M. Hanafi (2016), defines risk as an adverse event and an investment analysis, which is the possible outcome obtained from the expected. A standard deviation is a statistical tool that can be used to measure variation. Therefore, the standard deviation can be used to measure risk. The manager of an organization's job is to make the organization able to anticipate and take responsibility; in other words, the manager's job is to make the organization aware of risks so that risks are managed properly. According to SBC Warburg, The Practice of Risk Management, Euromoney Book, 2004 in Mamduh M. Hanafi (2016), risk management is a set of policies, complete procedures, which an organization has to monitor and control the organization's exposure to risk. There is a direct relationship between the goals an organization wants to achieve and the components of the company's risk 
management that represent what it takes to complete them. These relationships are represented in a three-dimensional matrix in cube form. This three-dimensional depiction illustrates an organization's ability to focus on total corporate risk management (COSO ERM, 2004). The third dimension is the company's strategy, operational, reporting, and compliance objectives, which are evaluated for risk management considerations. The risk component model consists of internal environment, goal setting, event identification, risk assessment, risk response, control activities, information and communication, and monitoring. Business entity organizational level spreads from top to bottom: entities, business units, subsidiaries, and divisions.

\section{Corporate Governance}

In general, corporate governance includes share ownership, corporate financing, auditing, audit committee, the board of directors, and management compensation. In this study, the moderating variable used was the number of audit committee meetings. The formal audit committee meeting is essential to the success of the audit committee. In each Charter, the Audit Committee asks that the audit committee will meet periodically and can hold additional meetings or special meetings if needed. Based on the effective Guidelines for the Establishment of an Audit Committee, it states that the audit committee must meet every 3 (three) months or 4 (four) times a year (FCGI, 2002). The audit committee can hold executive meetings with parties invited by the invited audit committee as needed or periodically (Sukarno, 2016).

The main objective of GCG is to create a control and balance system (checks and balances) to prevent misuse of company resources and encourage company growth. A good GGC must provide the right incentives for boards and management to pursue goals for the benefit of the company and its shareholders and facilitate effective oversight (OECD, 2004).

\section{Hypothesis Development}

\section{Information Technology Governance to Firm Performance}

IT governance is the responsibility of management in an organization, so that how IT can be more efficient and effective in supporting the business processes that are carried out. The objectives of IT governance control its use in ensuring that IT performance meets and is following the goals, including aligning information technology with company strategy and the realization of the benefits that have been published from IT application, the use of information technology that allows companies to take existing opportunities, as well as maximizing IT utilization in the advantages of implementing IT, being responsible for the use of IT resources, managing the risks that exist in the right information technology.

There are previous studies of IT Governance on firm performance. Ira Hapsari (2015), surveyed to analyze Good IT Governance's effect on financial performance in banks listed on the Indonesia Stock Exchange, and 13 samples fulfilled the research. 
In the research results, it is said that Good IT Governance has a positive effect on ROA; it is also noted that organizational governance's operation makes the technology system in banking, especially EB services, more integrated, configured running an orderly manner. If there are problems and obstacles, they can be resolved quickly. The online system makes all banking services smoother and more reachable wherever and whenever. Ardiany (2018), researched the effect of information technology governance mechanisms on organizational performance mediated by strategic alignment in all medium and high-income companies in Indonesia. The research results show that the Information Technology Governance Mechanism (MKTI) affects Organizational Performance. Widyaningsih (2019), examines how the impact of IT Governance and IT Operational Capability on the company's financial and non-financial performance can be mediated through investment in the IT sector. The results show that B-ITG and IT operating capabilities influence the organization's financial performance and non-financial performance. IT investment moderates B-ITG and IT's effect using powers on the organization's financial performance and non-financial performance.

Based on the discussion above, the hypothesis is as follows:

H1: IT Governance has a positive effect on Company Performance.

\section{Enterprise Risk Management to Firm Performance.}

The Committee of Sponsoring Organizations (COSO), in September 2004, published ERM as a corporate risk management process that is designed and implemented into every organization's strategy to achieve organizational goals. ERM disclosure is information relating to an organization's commitment to managing risk. Enterprise Risk Management is a set of policies created to facilitate an organization in achieving its goals with complete procedures related to response to the risks it faces.

There are previous studies regarding the effect of ERM on company performance. Oka Aditya and Prima Naomi (2017), in their research, say that the existence of ERM has a significant positive correlation with leverage; it can be seen that the presence of ERM convinces creditors to provide loans to companies in the construction and property sectors. Companies that implement ERM seem to be more diligent in distributing dividends to their investors; this is a positive sign for investors. Sunitha Devi et al. (2017), in their research results, said that ERM disclosure has a positive effect on firm value, which means that the more ERM disclosure items published by the company, the impact on the higher firm value. It was also said that the wide range of voluntary ERM information published by companies has a positive response by the market because the market believes that ERM disclosure can be used as one of the relevant information in predicting the future and going concerned about a company. Muslih (2018), conducted a study to study the benefits of ERM in improving company performance, and the research results showed a significant relationship between ERM and company performance. 
Adie Pamungkas (2019), shows that corporate risk management influences Firm Value in data testing works. Based on the calculation results, So $4.186 \mathrm{t}$ count $>2.02 \mathrm{t}$ table. At the same time, the level of significance is $0.000<0.05$. This shows that ERM has a positive effect on Firm Value.

Based on the discussion above, the hypothesis is as follows:

H2: Enterprise Risk Management has a positive effect on firm performance.

\section{Corporate Governance moderates the influence of Information Technology Governance on Company Performance.}

The concept of IT Governance is a way of managing the use of information technology in an organization. IT Governance combines good practices from planning and organizing, developing and implementing, delivery and support, and monitoring information system performance to ensure that information and related technology supports the achievement of organizational goals and missions.

The formal audit committee meeting is essential for the successful performance of the audit committee. In each Audit Committee Charter, it is stated that the audit committee will meet for meetings periodically and may hold additional meetings or special meetings if needed. Based on the effective Guidelines for the Establishment of an Audit Committee, it states that the audit committee must hold a meeting at least every 3 (three) months or 4 (four) times a year (FCGI, 2002). The audit committee can hold executive meetings with parties outside the audit committee members invited as needed or periodically, (Sukarno, 2016).

The implementation of information technology governance within the company must always be monitored, so that information technology is carried out following applicable standards. To watch and find out whether information technology governance is carried out properly and there are no violations against it, it is necessary to hold a meeting or discussion related to a review of the implementation and compliance with laws and regulations about information technology governance. Also, in audit committee meetings, evaluations and recommendations are made regarding information technology governance. The meeting held by the audit committee produces something that can encourage the implementation of information technology governance to be even better.

Based on the discussion above, the hypothesis is as follows:

H3: Corporate Governance moderates the influence of IT Governance on Company Performance.

\section{Corporate Governance moderates the influence of Enterprise Risk Management on Company Performance.}

Enterprise Risk Management is a set of policies created to facilitate an organization in achieving its goals with complete procedures related to response to the risks it faces. SBC Warburg, The Practice of Risk Management, Euromoney Book, 
2004 in Hanafi (2016), said that risk management is a set of policies, complete procedures, which an organization has to manage, monitor control an organization's exposure to risk.

In the audit committee's report to the board of commissioners, the audit committee provides conclusions from discussions with the external auditors regarding their findings relating to the mid-year review and annual financial statements, recommendations on the appointment of external auditors, and any resignation, replacement, and termination of the engagement, conclusions about the value of internal audit function and responses to internal audit findings, as well as conclusions on the performance of the internal control system ( Sukarno, 2016).

The company's implementation of risk management is to manage, monitor, and control the organization's exposure to risk. This will result in a good value for the company, such as minimizing the risk of loss or other threats that can harm the company. The audit committee is in charge of assisting the commissioners' board in carrying out its supervisory function over company activities related to reviewing financial information, internal control, and risk management. In audit committee meetings, reviews related to risk management will help the company evaluate the risks it faces and provide appropriate recommendations. The number of audit committee meetings can encourage the company to implement risk management with evaluations and recommendations.

Based on the discussion above, the hypothesis is as follows:

H4: Corporate Governance moderates the influence of Enterprise Risk Management on Firm Performance.

\section{METHODS}

This research uses quantitative research methods. Data processing is carried out by ordinary least squares (OLS). The quantitative research model is formulated as follows: $\mathrm{Y}=\alpha+\mathrm{b} 1 \mathrm{X} 1+\mathrm{b} 2 \mathrm{X} 2+\mathrm{b} 3 \mathrm{X} 3 \mathrm{X} 1+\mathrm{b} 4 \mathrm{X} 3 \mathrm{X} 2+\mu$.

Where $\mathrm{Y}=$ company performance, $\alpha=$ Constant, $\mathrm{b}=$ regression coefficient for each independent variable, $\mathrm{X} 1=$ Information Technology Governance, $\mathrm{X} 2=$ Enterprise Risk Management, X3X1 = Moderation of corporate governance on information technology governance, and $\mathrm{X} 3 \mathrm{X} 2=$ Moderation of corporate governance on risk management.

The unit of analysis is State-Owned Enterprises. The population is StateOwned Enterprises in the non-public financial sector. Return On Assets (ROA) measures company performance. Because ROA is a measure of a company's effectiveness in generating profits by utilizing its assets, its performance will be reflected in the ROA; if a company's ROA is high, its performance is good. Return On Asset (ROA) can be formulated as follows: 


\section{Return on Assets $=\underline{\text { Net Profit After Tax x 100\% }}$ \\ Total Assets}

The measurement of information technology governance implementation is measured using a Likert scale. The IT implementation stages used are as follows:

1. There are management and IT organization

2. There are IT applications and IT information

3. There is IT in use

4. There is a security system for IT used.

The IT implementation stages above are based on the Regulation of the Minister of State-Owned Enterprises of the Republic of Indonesia Number Per-02 / MBU / 02/2018 concerning the Principles of Information Technology Governance of the Ministry of State-Owned Enterprises. ERM is measured using a Likert scale. The ERM instruments used in this study consists of event identification, risk identification, risk analysis, and risk treatment/risk mitigation.

This research data is secondary data. The population is State-Owned Enterprises in the field of non-public finance. The sample is 17 State-Owned Enterprises in the field of non-public finance with 5 years of observation. Data analysis carried out will include data normality test. The data normality test is to determine whether the data is normal or not so that it is feasible to be regressed and used as a basis for making conclusions and decisions. Apart from the normality test, multicollinearity test, heteroscedasticity test, and serial correlation test was also performed. The regression test consists of the $\mathrm{F}$ test and the $\mathrm{t}$-test. The $\mathrm{F}$ test is to determine the overall effect (simultaneously) of the independent variable on the dependent variable (with the F significance indicator). The t-test determines one independent variable's partial result on the dependent variable (with the $t$ significance indicator).

\section{RESULTS AND DISCUSSION}

The descriptive statistical analysis describes research data from the mean, median, standard deviation, minimum value, and maximum value. This test is done to make it easier to understand the statistical data result.

Table 1 Descriptive Statistics Results

\begin{tabular}{|c|c|c|c|c|c|c|}
\hline & ROA & $\mathrm{C}$ & ERM & IT & JPKAERM & JPKAIT \\
\hline Mean & 0.047925 & 1.000000 & 2.988235 & 2.988235 & 53.28235 & 52.92941 \\
\hline Median & 0.036000 & 1.000000 & 3.000000 & 3.000000 & 45.00000 & 45.00000 \\
\hline Maximum & 0.339200 & 1.000000 & 4.000000 & 4.000000 & 208.0000 & 208.0000 \\
\hline Minimum & -0.040700 & 1.000000 & 1.000000 & 1.000000 & 3.000000 & 6.000000 \\
\hline Std. Dev. & 0.055309 & 0.000000 & 0.879585 & 0.809087 & 33.32188 & 32.85965 \\
\hline Skewness & 3.346905 & NA & -0.505164 & -0.385710 & 1.650446 & 1.801268 \\
\hline Kurtosis & 15.86844 & NA & 2.487430 & 2.534268 & 7.541076 & 8.026704 \\
\hline Jarque-Bera & 745.1801 & NA & 4.545697 & 2.875816 & 111.6236 & 135.4547 \\
\hline
\end{tabular}




\begin{tabular}{|lcccccc|}
\hline Probability & 0.000000 & NA & 0.103018 & 0.237424 & 0.000000 & 0.000000 \\
Sum & 4.073600 & 85.00000 & 254.0000 & 254.0000 & 4529.000 & 4499.000 \\
Sum Sq. Dev. & 0.256960 & 0.000000 & 64.98824 & 54.98824 & 93269.22 & 90699.58 \\
Observations & 85 & 85 & 85 & 85 & 85 & 85 \\
\hline
\end{tabular}

The collected data passed the classical assumption test.

Table 2 Simultaneous Significance Test (Test F)

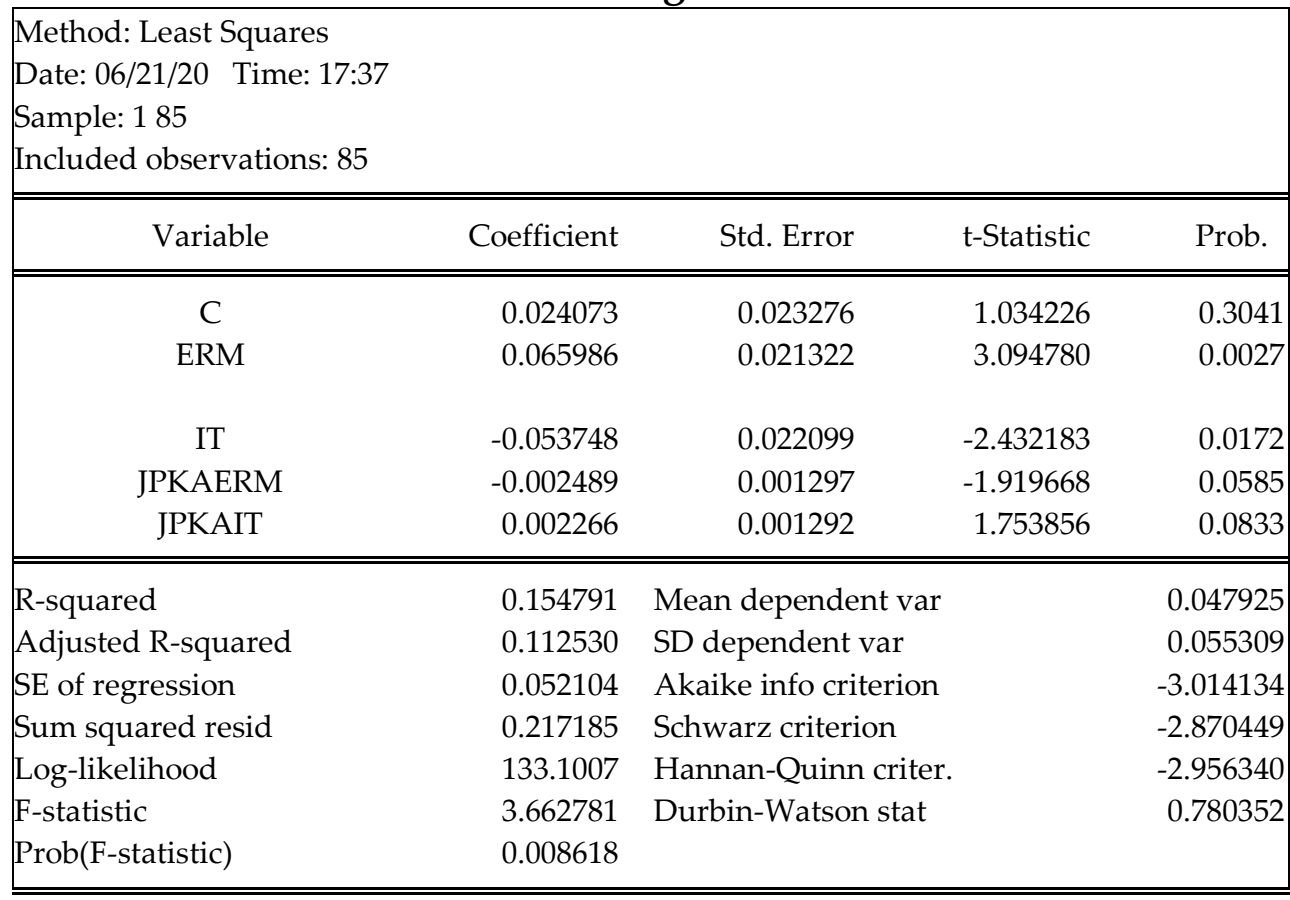

Based on the simultaneous significance test ( $\mathrm{F}$ test) results, the results show that Prob-F is 0.008618 . The F test result, which is less than 0.05 , indicates that the regression model can predict firm performance. It can be said that IT Governance and ERM together are proven to have a significant effect on corporate performance moderated by corporate governance.

Table 3 Significant Test for Individual Parameters (t-test)

\begin{tabular}{|c|c|c|c|c|}
\hline \multicolumn{5}{|c|}{$\begin{array}{l}\text { Method: Least Squares } \\
\text { Date: 06/21/20 Time: } 17: 37 \\
\text { Sample: } 185 \\
\text { Included observations: } 85\end{array}$} \\
\hline Variable & Coefficient & Std. Error & $\mathrm{t}$-Statistic & Prob. \\
\hline C & 0.024073 & 0.023276 & 1.034226 & 0.3041 \\
\hline ERM & 0.065986 & 0.021322 & 3.094780 & 0.0027 \\
\hline IT & -0.053748 & 0.022099 & -2.432183 & 0.0172 \\
\hline JPKAERM & -0.002489 & 0.001297 & -1.919668 & 0.0585 \\
\hline JPKAIT & 0.002266 & 0.001292 & 1.753856 & 0.0833 \\
\hline
\end{tabular}


Based on the results of the t-test above, the product is that the ERM prob is $0.0027<0.05$. This shows that ERM has a significant effect on company performance. Based on the results of the t-test above, the results show that the ITG probability is $0.0172<0.05$. This indicates that ITG has a significant effect on company performance.

Based on the results of the t-test above, the results show that the prob JPKAERM $0.0585<0.05$. This indicates that the number of audit committee meetings significantly moderates the effect of ERM on company performance.

Based on the results of the t-test above, the results show that the JPKAIT probability is $0.0833>0.05$. This indicates that the number of audit committee meetings moderates the little influence of ITG on company performance.

\section{The Effect of IT Governance on Firm Performance.}

IT governance has a significant negative effect on the performance of StateOwned Enterprises in the field of non-public finance for the period 2014-2018. This is evidenced by the ITG coefficient value, namely -0.053748 , and the prob value 0.0172 , which is smaller than the significance level of 0.05 so that the first hypothesis is not proven. The results of testing the first hypothesis state that there is a negative relationship between the implementation of information technology governance on company performance, which is proxied by Return on Assets (ROA), which means that the greater the IT investment in the company, the lower the company's performance will be. Because the implemented information technology does not comply with the applicable IT governance standards, information technology governance implemented within the company is only a written statement in a company's annual report. Still, in reality, it is not implemented properly. Thus, the IT'sestment senseless because it does not support company performance, which means that it cannot increase Return On Assets (ROA).

The results of this study indicate that IT governance has a negative and significant effect on company performance, which means that information systems do not implement the existence of information technology and government following predetermined policies. This means that the presence of IT increases the burden on the company, with unbalanced results. Meanwhile, investment in IT requires a very high cost. If the company can take full advantage of the IT owned and following the applicable IT governance standards, it will encourage value creation in the company; this will also impact increasing its Return On Asset (ROA).

This study's results are in line with Carl and Les (2011) research, which showed that the majority of organizations have corporate governance. Still, they do not comply with IT and IT project governance. In his study also said that there is an interesting fact. Namely, most organizations do not fully comply with IT governance requirements. According to him, organizations need to implement IT governance in COBIT, if not for good management, to improve IT-related investments and increase profits. 


\section{The Effect of Enterprise Risk Management on Firm Performance.}

Enterprise Risk Management (ERM) has a significant positive effect on the performance of State-Owned Enterprises in the field of non-public finance for the period 2014-2018. This is evidenced by the ERM coefficient value of 0.065986 and a prob value of 0.0027 , which is smaller than the significance level of 0.05 so that the second hypothesis is proven. The test results which state that ERM has a significant positive effect on company performance, which is proxied by using Return On Assets (ROA), shows that companies in the financial sector are very vulnerable to risks to data related to finance, or threats of fraud that may come from parties. Internal company related to finance. This will be anticipated by risk management in a company that is running well. The eight components of risk management, according to COSO, have a direct relationship with the goals the company wants to achieve because company risk management represents what is needed to achieve company goals.

The eight components of risk management, according to COSO, have a direct relationship with the goals the company wants to achieve because company risk management represents what is needed to achieve company goals. This relationship is depicted on a three-dimensional matrix in the form of a cube.

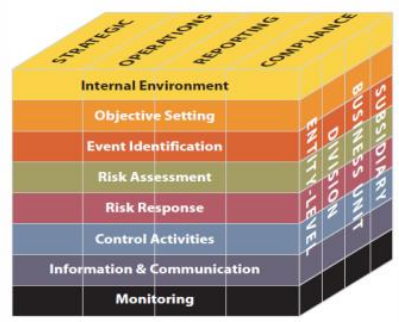

Figure 1 Relationship Between Objectives, Components, and Entities in ERM Source: COSO Executive Summary

The three-dimensional depiction illustrates the organization's ability to focus on the overall risk management of the company. The implementation of risk management in a company is very necessary, especially State-Owned Enterprises in the financial sector. Risk management is carried out to assess the risk's nature and design an appropriate response to it. The purpose of implementing risk management in the company is to minimize the impact of losses that will be faced by the company and maintain the maximum value that exists in all organizational activities. In this study, ERM has a positive and significant effect on company performance, which is proxied by using ROA because it has assessed the nature of risk, created a risk map, and established appropriate mitigation measures to encourage company performance.

The results of this study are in line with research conducted by Aditya and Naomi (2017), Devi, Budiasih and Badera (2017), Muslih (2018), and Pamungkas (2019) which in their research results show that Enterprise Risk Management has a significant positive effect on firm value. The results of this study are also in line with agency theory. Agency theory emphasizes that management as an agent is 
appointed by shareholders (principals) to manage the company and ensure that the funds are not misused by company management to fund unprofitable activities. With the application of ERM within the company, it will encourage investors' positive perceptions of the company, and this positive perception will affect increasing company value.

\section{Corporate Governance Moderating the Influence of IT Governance to Firm Performance.}

Corporate governance that is proxied by the number of audit committee meetings does not moderate the effect of Information Technology Governance on the Performance of State-Owned Enterprises in the field of non-public finance for the period 2014-2018. This is evidenced by the value of the JPKAIT coefficient of 0.002266 and the prob value of 0.0833 , which is greater than the significance level of 0.05 so that the third hypothesis is not proven. The test results, which state that corporate governance, which is proxied by the number of audit committee meetings does not moderate the effect of Information Technology Governance on company performance, indicates that the quantity of audit committee meetings does not encourage or strengthen the impact of information technology governance on company performance. The presence of the audit committee is very important for the company; the task of the audit committee is to supervise the implementation of the board of commissioners and improve the quality of information flow between shareholders and managers to help reduce agency problems and increase firm value (Obradovich and Gill, 2013) in Onasis and Robin (2016). However, besides being able to improve company performance, the audit committee can also reduce company performance. One of them is the number of audit committee meetings that are often held in one period. The more frequent sessions are owned by the audit committee but do not provide quality in meeting results, which means that meetings are held without being followed by an increase in performance. This can be due to the number of costs incurred by the company in every audit committee meeting; if audit committee meetings are held frequently, there will be an increase in the number of expenses incurred for the conference; besides, the implementation of information technology governance also requires a large amount of money so that the number of audit committee meetings does not strengthen the effect of information technology governance implementation on company performance.

\section{Corporate Governance Moderates The Influence Of Enterprise Risk Management On Company Performance.}

Corporate governance that is proxied by the number of audit committee meetings does not moderate the effect of risk management on the performance of State-Owned Enterprises in the field of non-public finance for the period 2014-2018. This is evidenced by the value of the JPKAERM coefficient of -0.002489 and the prob value of 0.0585 , which is greater than the significance level of 0.05 , so that the fourth hypothesis is not proven. The test results, which state that corporate governance 
proxied by the number of audit committee meetings does not moderate risk management on company performance, indicates that the number of audit committee meetings does not encourage or strengthen risk management implementation on company performance. However, besides being able to improve company performance, the audit committee can also reduce company performance.

One of them is the number of audit committee meetings that are often held in one period. The more frequent sessions are controlled by the audit committee but do not provide quality in meeting results, which means that meetings are held without being followed by an increase in performance. Octavianto, Widagdo, and Chariri (2014), said that many audit committee meetings in one year might improve the supervisory function's quality. Still, it can also cause delays in decision making related to the supervisory role so that it does not contribute to improving company performance. The number of audit committee meetings does not contribute to risk management implementation on company performance. Which means what question marks are made at each session? Has it been implemented effectively? If not, it is necessary to re-monitor each audit committee meeting activity so that it will be able to produce a recommendation or evaluation report on the company's operational activities, which will also have an impact on improving company performance.

\section{E. CONCLUSIONS}

The purpose of this research is to study the implementation of the regulations of the Ministry of State-Owned Enterprises number per02 / MBU / 2013 regarding the guidelines for the preparation of information technology for state-owned enterprises in the non-public financial sector, as well as to see the effect of risk management implementation on the performance of State-Owned Business Enterprises moderated by corporate governance. The population in this study are state-owned enterprises in the non-public financial sector. The research sample was 17 State-Owned Business Enterprises, which were sampled by purposive sampling. The analysis technique used is multiple linear regression. Based on the results of research and discussion, it can be serviced as follows: 1. IT Governance has a significant negative effect on the performance of State-Owned Enterprises in the field of non-public finance for the period 2014-2018, so the first hypothesis is not proven. 2. Enterprise Risk Management (ERM) has a significant positive effect on the performance of State-Owned Enterprises in the field of non-public finance for the period 2014-2018 so that the second hypothesis is proven. 3. Corporate governance that is proxied by the number of audit committee meetings does not moderate the effect of Information Technology Governance on the Performance of State-Owned Enterprises in the field of non-public finance for the 2014-2018 period, so the third hypothesis is not proven. 4 . Corporate governance as proxied by the number of audit committee meetings does not moderate the effect of risk management on the performance of State-Owned Enterprises in the field of non-public finance for the 2014-2018 period, so the fourth hypothesis is not proven. 
Based on the above conclusions, this study's suggestions are as follows: 1 - the importance of implementing information technology governance within the company in encouraging company performance. Information technology governance that is owned should be optimized again in its implementation. Because basically, the concept of IT Governance is a way of managing information technology in an organization. Especially in the financial sector, the confidentiality of customer data or financial-related data must be maintained not easily to be stolen by other parties. 2. Risk management that is already running well within the company would be better to be further improved. Because the existence of risk management is very supportive of the achievement of company goals. 3. A meeting conducted by the audit committee should also boost the company's performance if it is done well and produces good quality. So, every meeting held will make a report or conclusion that can evaluate the company's performance. 4. Future researchers who wish to research similar topics are expected to increase the research object's scope by extending the observation period. Apart from that, it can also use different company sectors. In this study, the moderating variable is corporate governance, which is proxied by the number of audit committee meetings. Further researchers can add other corporate governance components such as share ownership structure, corporate financing, auditing, a board of directors, and management compensation.

\section{REFERENCES}

1. Addiyah, A. (2014). Pengaruh Penerapan Corporate Governance Terhadap Kinerja Keuangan Perbankan. Skripsi. Ekonomika, F., Bisnis, D. A. N., E Diponegoro, U

2. Aditya, O., \& Naomi, P. (2017). Penerapan Manajemen Risiko Perusahaan Dan Nilai Perusahaan Di Sektor Konstruksi Dan Properti. Esensi: Jurnal Bisnis Dan Manajemen, 7(2), 167-180.

3. Akal, N. M., \& Akal, U. A. T. (2014) Govermance, C. (N.D.). Naskah Buku Lengkap. $1-162$.

4. Alon, I., Wang, H., Shen, J., \& Zhang, W. (2014). Chinese State-Owned Enterprises Go Global. Journal Of Business Strategy.

5. Andrianti, A., \& Assegaff, S. (2018). Analisis Dan Perancangan It Governance Menggunakan Framework Cobit Pada Pengelolaan Data Pt . Bpr Us. Jurnal Manajemen Sistem Informasi, 3(2), 989-998.

6. Anggitarani, A. (2009). Pengaruh Corporate Governance, Etnis Dan Latar Belakang Pendidikan Terhadap Kinerja Keuangan Perusahaan: Studi Empiris Pada Perusahaan Publik Yang Terdaftar Di Bursa Efek Indonesia. Skripsi. Fakultas Ekonomi Universitas Sebelas Maret Surakarta.

7. Ardiany, Y. (2018). Pengaruh Mekanisme Tata Kelola Teknologi Informasi Terhadap Kinerja Organisasi Dengan Keselarasan Strategi Sebagai Variabel Intervening. Jurnal Profiet, 2(46), 141-147. 
8. Bowen, P. L., Cheung, M. Y. D., \& Rohde, F. H. (2007). Enhancing It Governance Practices: A Model And Case Study Of An Organization's Efforts. International Journal Of Accounting Information Systems, 8(3), 191-221.

9. Creswell, J. W. (2019). Research Design Qualitative, Quantitative, And Mixed-Method Approaches. Third Edition. Yogyakarta: Pustaka Pelajar.

10. Decree Of The Secretary Of The Ministry Of State-Owned Enterprises (Sk Sekmen BUMN) No.Sk-16 / S.Mbu / 2012 Concerning Indicators / Parameters For Assessment And Evaluation Of The Implementation Of Gcg In BUMN.

11. Devi, S. (2017). Pengaruh Pengungkapan Enterprise Risk Management Dan Pengungkapan Intelectual Capital Terhadap Nilai Perusahaan (The Effect Of Enterprise Risk Management Disclosure And Intellectual Capital Disclosure On Firm Value). Jurnal Akuntansi Dan Keuangan Indonesia, 14(1), 20-45.

12. El-Chaarani, H. (2014). The Impact Of Corporate Governance On The Performance Of Lebanese Banks. The International Journal Of Business And Finance Research, 8(5), 22-34

13. Fasilkom, T. D. (2017). Tata Kelola It. Modul Standar Untuk Digunakan Dalam Perkuliahan Di Universitas Mercu Buana.

14. Forum For Corporate Governance In Indonesia (Fcgi). (2002). Peranan Dewan Komisaris Dan Komite Audit Dalam Pelaksanaan Corporate Governance (Tata Kelola Perusahaan). Jakarta.

15. Forum For Corporate Governance In Indonesia (Fcgi). (2001). Seri Tata Kelola Perusahaan (Corporate Governance), Edisi Ke-2 Jakarta.Tata Kelola It. Modul Standar Untuk Digunakan Dalam Perkuliahan Di Universitas Mercu Buana.

16. Ghozali, I. (2007) . Aplikasi Analisis Multivariate Dengan Program Spss. Semarang: Badan Penerbit Universitas Diponegoro.

17. Girma, S., Gong, Y., \& Görg, H. (2009). What Determines Innovation Activity In Chinese State-Owned Enterprises? The Role Of Foreign Direct Investment. World Development, 37(4), 866-873.

18. Gunawan, B., \& Pratama, A. F. (2018). Perancangan Tata Kelola Teknologi Informasi. Yogyakarta: Penerbit Andi.

19. Hakim., Saragih., \& Suharto. (2014). Evaluasi Tata Kelola Teknologi Informasi Dengan Framework Cobit 5 Di Kementerian Esdm (Studi Kasus Pada Pusat Data Dan Teknologi Informasi Esdm). Jurnal Sistem Informasi (Journal Of Information Systems). 2/10 (2014), 108-117.

20. Hamsir, M. A., \& Juardi, M. S. S. (2017). Analisis Penerapan It Governance Menggunakan Cobit Framework Dan Sarbanes Oxley Dalam Mendukung 
Corporate Financial Performance (Studi Kasus Pada Pt. Telkom). Jurnal Ilmiah Akuntansi Peradaban, 3(2).

21. Hapsari, Ira., Haryadi, H., \& Wiratno, A. (2017). Implikasi Good It Governance Terhadap Kinerja Keuangan Perusahaan Dengan Intellectual Capital Sebagai Variabel Mediasi ( Studi Pada Perbankan Yang Terdaftar Di Bursa Efek Indonesia ). Simposium Nasional Akuntansi, 1-26.

22. It Governance Institute (It), Isaca. (2012). Cobit Student Book. United States Of America

23. Kanhai, C., \& Muhwandavaka, R. (2014). An Investigation Of The Extent Of Adoption Of Enterprise Risk Management (Erm) By Banks In Zimbabwe. International Journal Of Business And Commerce, 3(37), 19-33.

24. Kusmayadi, D., Rudiana, D., \& Badruzaman, J. (2015). Good Corporate Governance. Hasil Reviewer, 1-158.

25. Liang, H., Ren, B., \& Sun, S. L. (2015). An Anatomy Of State Control In The Globalization Of State-Owned Enterprises. Journal Of International Business Studies, 46(2), 223-240.

26. Lunardi, G. L., Becker, J. L., Maçada, A. C. G., \& Dolci, P. C. (2014). The Impact Of Adopting It Governance On Financial Performance: An Empirical Analysis Among Brazilian Firms. International Journal Of Accounting Information Systems, 15(1), 66-81.

27. Mamduh, M. H. (2016). Manajemen Risiko Edisi Ketiga. Yogyakarta: Upp Stim Ykpn.

28. Marnewick, C., \& Labuschagne, L. (2011). An Investigation Into The Governance Of Information Technology Projects In South Africa. International Journal Of Project Management, 29(6), 661-670.

29. Maylisda, Frisca, Es. 2019. 17 Fakta Soal Kasus Jiwasraya, Dinilai Sembrono Hingga Gagal Bayar Polis. Retrieved From Https:/Economy.Okezone.Com/Read/2019/12/22/320/2144884/17-Fakta-Soal Kasus-Jiwasraya-Dinilai-Sembrono-Hingga-Gagal-Bayar-Polis? On July 20, 2020

30. Meizaroh \& Lucyanda, J. (2011). Pengaruh Corporate Governance Dan Konsentrasi Kepemilikan Pada Pengungkapan Enterprise Risk Management .Simposium Nasional Akuntansi Xiv Aceh 2011.

31. Moeheriono. (2012). Pengukuran Kinerja Berbasis Kompetensi. Jakarta: Raja Grafindo Persada.

32. Mulyadi, R. (2017). Pengaruh Karakteristik Komite Audit Dan Kualitas Audit Terhadap Profitabilitas Perusahaan (Studi Pada Perusahaan Perbankan Yang Terdaftar Di Bei Periode 2011-2015). Jurnal Akuntansi, 4(2), 22-35. 
33. Mulyati, T., \& Muslih, M. (2020). Pengaruh Sustainable Governance Terhadap Kinerja Perusahaan Perbankan Yang Terdaftar Di Bursa Efek Indonesia Dimoderasi Oleh Audit Internal. Jurnal Kewirausahaan, Akuntansi, Dan Manajemen Tri Bisnis, 2(2), 180-197.

34. Mungawanah. (2018). Pengaruh Enterprise Risk Management Terhadap Kinerja Perusahaan (Studi Pada Perusahaan Jasa Sektor Infrastruktur, Utilitas Dan Transportasi Terdaftar Bursa Efek Indonesia Tahun 2014 - 2016). Jurnal Ilmiah Mahasiswa Feb, 6(2).

35. Muslih, M. (2018). Tata Kelola Berkelanjutan Bagi Bumn Bidang Keuangan Non Publik. Firm Journal Of Management Studies. 4 (2).

36. Muslih, M. (2019). The Benefit Of Enterprise Risk Management (Erm) On Firm Performance. Indonesian Management And Accounting Research, 17(2), 168-185.

37. Muslih, M. (2019b). The Committee Of Audit Role On The State-Owned Enterprises ( BUMN) Performance Of Indonesia Registered On The Stock Exchange Of Indonesia Jel Classification: M41, M42. 1(2), 131-146.

38. Octavianto, D., Widagdo, K., \& Chariri. A. (2014) Pengaruh Good Corporate Governance Terhadap Kinerja Perusahaan. Diponegoro Journal Of Accounting. 3(3),

39. Oecd. (2004). The Oecd Principles Of Corporate Governance. France: Organization For Economic Co-Operation And Development (Oecd) Publications Service

40. Oltsik, J. (2003). Information Security Management: Analysis And Recommendations English. Hype-Free Consulting.

41. Onasis, K., \& Robin, R. (2016). Pengaruh Tata Kelola Perusahaan Terhadap Nilai Perusahaan Pada Perusahaan Sektor Keuangan Yang Terdaftar Di Bei. Bina Ekonomi, 20(1), 1-22.

42. Pamungkas, A. (2019). Pengaruh Penerapan Enterprise Risk Management (Coso) Terhadap Nilai Perusahaan:Studi Empiris Pada Perusahaan Manufaktur Yang Terdaftar Di Bei. Jurnal Akuntansi Maranatha, 11(1), 12-21.

43. Pedoman Pembentukan Komite Audit Yang Efektif. (2002). Compiled For Komite Nasional Good Corporate Governance.

44. Prasinta, D. (2012). Pengaruh Good Corporate Governance Terhadap Kinerja Keuangan. Accounting Analysis Journal 2(1), 4-17.

45. Ramlan, C., Rifa, D., \& Fauziati. (2013). Pengaruh Sistem Good Corporate Governance Terhadap Kinerja Keuangan Perusahaan. Jurnal Fakultas Ekonomi. Vol 6 No.1.

46. Regulation Of The Minister For State-Owned Enterprises Number Per-02 / Mbu / 2013 Concerning Guidelines For The Compilation Of Information Technology 
Management For State-Owned Enterprises. Minister Of Bumn Regulation No Per-02 / Mbu / 2013.

47. Regulation Of The Minister Of State For State-Owned Enterprises (Bumn) No: Per-01 / Mbu / 2011. Regarding The Implementation Of Good Corporate Governance In State-Owned Enterprises.

48. Regulation Of The Minister Of State-Owned Enterprises Of The Republic Of Indonesia Number Per-02 / Mbu / 02/2018. Regulation Of The Minister For StateOwned Enterprises Of The Republic Of Indonesia Concerning The Principles Of Information Technology Governance Of The Ministry Of State-Owned Enterprises.

49. Safitri, S. T. (2013). Analisis Information Technology Governance Pada Pt. Pertamina (Persero). Jurnal Infotel - Informatika Telekomunikasi Elektronika, 5(1), 52.

50. Satriadi, F., Kara, M. A. B., Pranoto, T., \& Haryono, L. (2018). Pengaruh Tata Kelola Perusahaan Terhadap Profitabilitas Pada Perusahaan Yang Terdaftar Di Bursa Efek Indonesia. Studi Akuntansi Dan Keuangan Indonesia, 1(2), 134-157.

51. Sugiono. (2011). Metode Penelitian Kuantitatif, Kualitatif Dan RED. Bandung: Pt Alfabet.

52. Sukarno. (2016). Pengaruh Karakteristik Komite Audit Terhadap Kualitas Audit (Studi Empiris Pada Perusahaan Manufaktur Yang Terdaftar Di Bursa Efek Indonesia). Jurnal Manajemen Dan Jurnal Akuntansi. Vol 1, No 1.

53. Summary, E. (2015). Enterprise Risk Management-Integrated Framework. SarbanesOxley Guide For Finance And Information Technology Professionals, September, 224232

54. The It G. I. (2000b). It Governance Executive Summary. It Governance Institute.

55. The It, G. I.. (2000a). Board Briefing On It Governance. It Governance Institute.

56. Tuarita, A. S. (2015). Pengaruh Penerapan Good Corporate Governance Terhadap Kinerja Keuangan (Studi Empiris Pada Perusahaan Manufaktur Yang Terdaftar Di Bursa Efek Indonesia Periode 2014). Skripsi. Fakultas Ekonomi Dan Bisnis Universitas Hasanuddin Makassar.

57. Wahyudi, E. (2020). Taspen Bukukan Laba Rp 388 Miliar Di 2019, Naik Hingga 43 Persen. Accessed 20 Juli 2020 From

Https:/Bisnis.Tempo.Co/Read/1300292/Taspen-Bukukan-Laba-Rp-388-MiliarDi- 2019-Naik-Hingga-43-Persen/Full\&View=Ok.

58. Wandeca, J. S., \& Liza, A., S. E. (2012). Analisis Pengaruh Pergantian Chief Executive Officer (Ceo) Terhadap Praktek Manajemen Laba (Studi Pada Perusahaan Bumn Dan Non Bumn Di Bursa Efek Indonesia). Jurnal Universitas Lampung. 
59. Weill, P., \& Ross, J. W. (2004). It Governance: How Top Performers Manage It Decision Rights For Superior Results. Harvard Business Press.

60. Widodo, I. (2011). Analisis Kinerja Perusahaan Dengan Menggunakan Pendekatan Balanced Scorecard (Studi Kasus Pada Perusahaan Mebel Pt. Jansen Indonesia). Skripsi. Fakultas Ekonomi Universitas Diponegoro Semarang. 1-1(Ff), 134.

61. Widyaningsih, H. (2019). Peran Investasi Ti Dalam Pengaruh It Governance Terhadap Kinerja Perusahaan. Prima Ekonomika, 10(2), 25-36.

62. Yi Lin, H. (2010). The Agency Problem In Taiwan's Corporate Governance. The Journal Of International Management Studies, 5(1), 11-22

63. Yudatama, U., Hidayanto, A. N., Nazief, B. A. A., \& Phusavat, K. (2019). Data To Model The Effect Of Awareness On The Success Of It Governance Implementation: A Partial Least Squares Structural Equation Modeling Approach (Pls-Sem). Data In Brief, $25,104333$. 